\title{
The hybrid legal geographies of a war crimes court
}

\section{Abstract}

This paper explores the implications of understanding war crime trials as hybrid legal spaces. Drawing on twelve months of residential fieldwork in the Court of Bosnia and Herzegovina, Sarajevo, it examines the circulation of evidence, the choreography of the court room and the nature and possibilities for legal observation. Analyzing hybrid legal geographies foregrounds the material and embodied nature of trials, illuminating the forms of comportment, categorization and exclusion through which law establishes its legitimacy. Rather than emphasizing separation and distance, the lens of hybridity illuminates the multiple ways in which war crimes trials are grounded in the social and political context of present day Bosnia and Herzegovina. Consequently this analysis traces the disjuncture between the imagined geographies of legal jurisdiction and the material and embodied spaces of trial practices. In conclusion we argue that the establishment of the Court of Bosnia and Herzegovina illustrates the tensions that emerge when an institution of trial justice is used to strengthen the coherence of a post-conflict state.

\section{Keywords}

Legal geography, Bosnia and Herzegovina, hybrid geographies, war crimes trials

\section{Authors}

Alex Jeffrey (corresponding author) asj38@cam.ac.uk

The Department of Geography,

The University of Cambridge,

Downing Place,

Cambridge, UK CB2 3EN 
Michaelina Jakala

The School of Geography, Politics and Sociology

Newcastle University

Daysh Building

Newcastle-upon-Tyne

NE1 7RU

\section{Acknowledgements}

This paper is based on research funded by the Economic and Social Research Council (RES-061-250479). We would like to thank all those who participated in the research in Bosnia and Herzegovina. We are grateful for the opportunity to discuss the research in seminars at Sheffield University, Queens University Belfast and the University of Cambridge. We also organised a session at the Annual Meeting of the Association of American Geographers in Los Angeles where we discussed these findings, we would like to thank the other participants and audience for helping refine the arguments. Alex would also like to thank Ash Amin, Craig Jeffrey and Robert MacFarlane for taking time to discuss aspects of this research. We are finally grateful to the very helpful suggestions of four anonymous referees and Richard Wright. All remaining errors are our own. 


\section{Introduction}

The production and enforcement of law involves processes of categorization. These are particularly evident in the case of international law, where geographical units are variously reconfigured, consolidated and transgressed through its operation. Rather than simply signaling an erosion of state legal sovereignty, the implementation of international legal codes and norms points to a more ambiguous set of geographical consequences as imaginaries of the 'international' and the 'domestic' are produced through its operation (Elden 2009; Gregory 2007). To critique these categorizations we can draw from the work of scholars of law over the past thirty years, much of it within geography, which has sought to explore how concepts of law and space are co-produced through the exercise of power (Blomley 2003, 2008; Delaney 2001). By rejecting an image of space as an inert backdrop against which legal codes unfold, this scholarship has led to a more profound criticism of the separation of social life from imagined apolitical legal principles (Blomley 1994, 34; Jeffrey 2011; McEvoy 2007). Adopting this perspective we can begin to critique the concept of international law, and explore instead the forms of spatiality that are produced under the label of being 'international.' Santos (1987) talks of the "supra-state" legal spaces produced through transnational capitalism, though this is not necessarily a contiguous territory or jurisdiction. As Ferguson (2006) has noted, the form of territorialization of such an entity is more likely to be an archipelago of enclaves adhering to specific legal norms than an expanding uniform legal territory. In these terms scalar rhetoric masks a fragmented and uneven geography. Building on such insights, we need a clearer engagement with the ontology, as opposed to the epistemology, of international law, as it unfolds in particular places and between particular peoples. This process highlights the potential break between the intentions of those designing judicial institutions and the outcomes that emerge through the day-to-day running of trial processes and court activity.

In this paper we will explore the spatial consequences of attempts to implement international criminal law in Bosnia and Herzegovina $(\mathrm{BiH})$, focusing in particular on the establishment of war 
crimes trials in the State Court of Bosnia and Herzegovina ( $\mathrm{CBiH}$ ) since 2005. The $\mathrm{CBiH}$ is located in former Jugoslovenska narodna armija (Yugoslav People's Army or JNA) barracks named 'Viktor Bubanj' located on Safeta Hadžiča five kilometers from the center of Sarajevo (see figures 1 and 2). Drawing on qualitative fieldwork carried out in October 2009 and between September 2011 and September 2012, we will argue that the trials at the $\mathrm{CBiH}$ need to be understood as hybrid performances, extending beyond simply the blurring of international or domestic scales. As trials unfold they illustrate the paradox of precise legal categorization conveyed through the disordered interweaving of humans, materials and language. By observing the unfolding of law over a sustained period of time we begin to trace the limits of war crimes trials and how the fragility of memory, evidence and bodies constrains the possibilities of legal resolution. While the theoretical rubric of this argument advocates complexity and difference; the objective of the paper remains modest: to explore hybridity to illustrate the divergence between expectations and outcomes in the workings of a new war crimes court. This matters because judgments of the success or failure of war crimes cases are often assessed from the perspective of numbers of indictments or completions of trials. It is only through an examination of trial processes as material and embodied performances that we can discern why they often remain incomplete or are delayed, why individuals and groups resist the work of the court and how local and international political manipulation of court practices can gain currency.

[Figure 1]

[Figure 2]

The hybrid legal geographies of the $\mathrm{CBiH}$ emerge both through the trial processes and the context of its creation. The conflict in BiH began in 1992, following the state's declaration of independence from the remnants of Yugoslavia (see Silber and Little 1995). The dynamics of the initial violence saw political and military leaders, in particular loyal to Serb causes, combine the desire for national security with the aspiration of territorial ethno-homogeneity (Campbell 1998; Toal and Dahlman 
2012). The attempt to carve the Republika Srpska as an ethnically pure territory out of the actual existing multi-ethnicity of the Yugoslav Republic of Bosnia required the expulsion or death of nonSerb populations, the destruction of non-Serb cultural and religious buildings and the consequent inscription of Serbian heritage on the landscape (Coward 2009). But as a significant deviation from international responses to previous conflicts, moves began early within the conflict, initiated by members of the UN Security Council, to view the violence committed on the territory of BiH as a violation of international law. That is, legal instruments and arguments were deployed while the violence was still taking place, rather than as a post-hoc form of retribution (see Goldstone 2000; Nettelfield 2010). Despite initial reticence (see Hazan 2004), following reports of 'ethnic cleansing' on the territory of BiH the UN Security Council established a Commission of Experts in 1992 with the mandate to investigate whether "grave breaches of the Geneva Conventions and other violations of international humanitarian law [were being] committed in the territory of the former Yugoslavia" (Commission of Experts 1994). Led by Law Professor Mahmoud Cherif Bassiouni, over the following years the Commission uncovered and documented numerous breaches of international humanitarian law, in particular noting the existence of detention camps, the expulsion of civilian populations and the summary execution of victim groups. For example in the case of the siege of Sarajevo by groups loyal to Serb causes, the Commission wrote:

[t]he cumulative effect of the number of civilian casualties, the destruction of non-military structures, attacks upon and destruction of protected targets, such as hospitals, cultural property and other impermissible targets, evidence a consistent and repeated pattern of grave breaches of the Geneva Conventions and other violations of international humanitarian law. (Commission of Experts 1994).

Under growing international concern relating to human rights abuses and in light of reporting of the Commission of Experts, on May 25 1993 the UN Security Council passed Resolution 827 
establishing the International Criminal Tribunal for the former Yugoslavia (ICTY) with headquarters at The Hague (see Armatta 2010; Hazan 2004; Nettelfield 2010).

From its initial design the ICTY was conceived as an ad hoc, and therefore temporary, judicial institution. Part of its 'completion mandate' comprises the devolution of war crimes cases and prosecution competences to national state courts in Serbia, Croatia and BiH. In August 2003 the UN Security Council passed Resolution 1503, which formally called upon national judiciaries in the former Yugoslavia to try cases against what were termed "low and mid-level war crimes perpetrators" (ICTY 2012a). This process of establishing a court and prosecution service had been fraught, as initial collaboration between the governments of the Muslim-Croat Federation and the Republika Srpska (the two 'entities' that, together with Brčko District, comprise BiH) and the Office of the High Representative ${ }^{1}(\mathrm{OHR})$ to draw up the necessary Law on the State Court of Bosnia and Herzegovina collapsed in 2000. Consequently Wolfgang Petrisch, then High Representative (head of the OHR), imposed the Law in November 2000. Following these initiatives two donor conferences were organized, first in The Hague (2003), where €15.7 million was pledged, and in Brussels (2006), where donors pledged $€ 7.7$ million. By 2005 the Court was in a position to accept transferred cases from the ICTY. The Court began with an integrated international and domestic judiciary, and in subsequent years international participation in the judicial panels has slowly declined. ${ }^{2}$

At this early stage the $\mathrm{CBiH}$ was a hybrid entity, where international funding and judiciary were supporting a purportedly 'national' court. Exploring the subsequent founding and operation of the court, we will argue that its spatial consequences are indeed hybrid but not simply in the integration of the imagined realms of the domestic and the international. The practice of the court itself is a performance of hybridity, where human and non-human agents intersect in producing varied imaginations of scale, space and place. In part these observations are not unique to the $\mathrm{CBiH}$ and could be applied to a range of legal settings. But we will argue that there is a specific need to explore hybridity in the case of attempts to establish transitional justice, that is "[..] a society's attempts to 
come to terms with a legacy of past abuses, in order to ensure accountability, serve justice and achieve reconciliation" (United Nations Security Council 2004, 4). Exploring the hybrid practices of law, with its attendant focus on material and social context of legal performances, challenges a purely legalistic understanding of transitional justice, where justice is largely understood through the study of legal processes and the perspectives of legal personnel (see Jeffrey 2011; McEvoy 2007). By its nature, a hybrid spatial perspective orientates attention to the embodied and situated nature of legal processes and the constructed nature of the distinction between law and non-law. This is particularly important in transitional contexts, where crimes are temporally remote and are further distanced when purely legal mechanisms are used to seek justice. Through the performance of law within a transitional setting we can observe how competing geographical practices and imaginaries interplay through traumatic recollections of the past, emerging alongside fantasies of nationalist homelands, played out through the recollections of aging, and often absent, witnesses.

To invoke hybrid legal geographies we have followed a qualitative and ethnographic research design, exploring legal practices as they unfold within $\mathrm{BiH}$. To capture this material we undertook a pilot study (October 2009) and a follow-up year of residential fieldwork in BiH (September 2011September 2012), the latter of which was divided into a series of concurrent data collection activities. The first comprised fifty open-ended interviews with representatives from the $\mathrm{CBiH}$ (in particular the Court Public Information and Outreach division), from wider judicial bodies such as the ICTY liaison team in Sarajevo, within other international organizations such as the Office of the High Representative, United Nations Development Program (UNDP), the European Commission and with international and local NGOs. Second, the research involved monitoring war crimes trials within the $\mathrm{CBiH}$, attempting where possible to track individual trials from the defense and prosecution arguments through to the verdict and (when relevant) sentencing. Through a continual process of note-taking, the monitoring attempted to capture the experience of attending the court, using anthropological techniques of listing the objects observed in the corridors and waiting rooms, noting the comportment and interactions of other trial attendees, in addition to descriptive accounts of 
legal processes, materials and interactions within the trials themselves (see Navaro-Yashin 2012). As discussed below, this style of material, architectural and bodily observation is crucial when adopting a theoretical perspective that foregrounds the significance of the non-textual in the production of legal outcomes. Thirdly, over the course of the fieldwork we attended public outreach events organized by the $\mathrm{CBiH}$, the ICTY or NGOs. These events were crucial in tracing the affective responses of groups and individuals to the operation of war crimes trials, often providing an insight into feelings of anomie and frustration at the pace or scope of legal processes. Finally, the research involved translating and reviewing institutional literature from the $\mathrm{CBiH}$, the ICTY and the NGO community.

This paper is divided into four further sections. In the first we examine the theoretical implications of using ideas of hybridity to examine war crimes trials. This material explores how legal scholarship over the past thirty years has looked beyond textual understandings of law, to explore instead the political and juridical implications of law as a socially and materially embedded performance. In a second section, we examine the implications of this theoretical material for our understanding of the foundation of the $\mathrm{CBiH}$. Rather than viewing the establishment of the $\mathrm{CBiH}$ as the birth of a new judicial institution, this section examines how hybrid geographies usher in a more complex temporality. In our argument we foreground the significance of the material form of the court to the nature of public imaginaries of trial justice and the possibilities of legal resolution. The third section explores the performance of law at the $\mathrm{CBiH}$, examining how audiences comprising victims and human rights NGOs are interpreting and challenging the practices of the $\mathrm{CBiH}$. Constructed through a series of trial events and arguments, we trace how a hybrid understanding of the trial processes illuminates interpretations of the achievement (or otherwise) of justice in $\mathrm{BiH}$. The conclusion outlines the meaning of these arguments for the fields of legal geography and transitional justice. 


\section{Hybrid Law}

A practical engagement with legal hybridity is freighted with theoretical consequences.

Foregrounding a hybrid approach requires challenging some of the cherished classifications that have organized social scientific thought. Perhaps most crucially, from this perspective the distinction between human and non-human agents becomes blurred and frayed, both through a focus on the assemblages of bodies and materials that comprise the social world, but also by querying the concept of the human body as a pristine unit detached from the material world. For Whatmore $(2002,3)$ this duality is at the heart of the hybrid geographical approaches that attend "simultaneously to the inter-corporeal conduct of human knowing and doing and to the affects of a multitude of other 'message-bearers' that make their presence felt in the fabric of social life." Questioning the human/non-human binary has a series of implications for the study of society. First, it centers on categorization as a form of primary distancing: that the separation of humans from nature and technology allows "easy distinctions to be made between some subjects as pure and others as impure, some as citizens and others as strangers" (Amin 2012, 2). An embodied and situated account can begin to trace the entanglements of the material and the technology that shape the possibilities of bodily encounters and practices.

Second, adopting a hybrid approach fosters skepticism as to the unitary nature of the institutions under examination. This approach is not the exclusive preserve of hybrid geographies; for some time scholars in other areas of the social sciences have sought to provide anti-essentialist or postfoundational accounts of discourses, practices and bodies (Butler 1990; Derrida 1994). Reflecting these perspectives, hybrid approaches have avoided using categories or organizations as points of departure, exploring instead the unitary nature of such institutions as a "precarious achievement" (Law 1994, 101; cited in Whatmore 2002, 4). In doing so, hybrid perspectives have fostered attention on the 'event' rather than the institution, group or individual as an object of analysis. As Amin (2012, 5) notes "the entanglements of situated practice are taken seriously by interrogating the multiple 
provenances of judgment that envelope the event - mediated and direct, immediate and remote, purposeful and unintentional, cognitive and non-cognitive, archived and actual."

Exploring legal hybridity, then, requires an examination of the "multiple provenances of judgment" that shape and situate legal practices. This approach orientates attention to trials as forms of performance or improvisation, where agents (both human and non-human) actively constitute law through gestures, iterations and dispositions. This approach, popularized by legal anthropologists exploring the relationship between law and theatre, marks a significant shift away from understanding law as a textual practice structured around legal codes and constitutions. From the outset this is more than simply about the medium through which law is understood: it orientates the discussion to the primary questions of what constitutes law. As Cover $(1985,180)$ states in his landmark exegesis concerning the practice of law, on a political level law "connotes legitimacy in the exercise of coercion and in the organization of authority and privilege," while on a philosophical level it connotes "universality and objectivity." The turn to exploring legal theatricality can be understood as part of a wider move to challenge such assertions of universality, and explore instead the resources, bodies and actions that articulate to accomplish law. Perhaps the most prominent example of a theatrical interpretation of legal practice is contained in Arendt's (1963) account of the trial of Nazi bureaucrat Adolf Eichmann. According to Arendt, the design of the trial exceeded its juridical function and attempted instead to fulfill a wider dramatic purpose: to act as a stage on which the crime of the Holocaust could be signified through the actions of Adolf Eichmann. But while Arendt is critical of the theatrics of the proceedings, suggesting this distracts from its juridical purpose, others view a theatrical interpretation as a mechanism to capture all that exceeds law in the performance of a trial. For example, Felman (2002) examines the moment during the Eichmann trial when witness Yehiel De-Nur (the author K-Zetnik) collapsed while giving testimony to his experiences in Auschwitz. For Felman $(2002,159)$ this moment points to the limits of legal discourse, illustrating "the tragic unnarratability of the ungraspable disaster and of its immeasurably devastating, unintelligible trauma." 
Felman illustrates that performance can convey something beyond the text, but there are philosophical schisms as to how we understand the relationship between performance and law. The legal scholar Julie Stone Peters has long studied the relationship between legal practices and theatricality, arguing that trials "exploit iconic props as crucial clues to the unfolding of the narrative, and often rely on space, staging, costume, and spectacle in an attempt to bring back to life the dramatic event they are attempting to recount" (Peters 2008, 181). This point is extended by Mulcahy (2011) in her recent exploration of the design and architecture of law courts and court rooms. For Mulcahy $(2011,1)$ the design of the court has implications for wider understandings of the nature and independence of judicial practices:

Each time a section of floor is raised, a barrier installed or a segregated circulation route added it has the potential to create insiders and outsiders; empowered and disempowered participants in a space ostensibly labeled 'public' in which the intricacies of civil liberties and participatory democracy are played out.

In this account the court is not a neutral backdrop to the trial process, but rather its architecture, materials and spatial organization shape the production of law. But Peters goes further, to suggest that studying the performance of law is not simply a more contextualized means through which legal nuance may be captured, rather the performance of law (its unfolding or doing) is constitutive of its force and authority. Consequently like others - most notably Bourdieu (1986), Derrida (1994) and Butler (1990) - Peters is keen to point to the performative force of the staging of law, where rites, ceremonies, dress and comportment are themselves central to the articulation of authority. Within this conceptual framework it is not that law is enacting a pre-existing form of authority, but rather law is actively constituted through such actions.

This performative point extends beyond simply the creation of the law/non-law distinction. As Pottage (2004) has illustrated, the practice of law is constitutive of a range of classificatory acts, where distinctions are reified between people and things. Whether material evidence, an executed 
corpse, a testifying witness or an indicted defendant, legal practice performs distinctions and thus brings them into being. But, of course, these are not simple classifications to render, as Arsenijević (2011) illustrates in his study of the cataloguing of mortal remains in Bosnia and Herzegovina after the 1992-5 war. Attempts to identify the mortal remains of missing persons have illuminated a tension between legal decision-making and collective trauma, as collections of bones are granted legal force as a human body, while other material or mortal remains are discarded or overlooked. Arsenijevićs $(2011,194)$ prose punctures the supposed clinical rationality of law:

Now I ask you: what would you decide to name a set of mortal remains - a femur, a rib, a tooth, part of a skull - as a body, with full identity and history? Are a femur, a tooth, a rib and part of the skull enough for you? What is the bare minimum you would identify as a body, would you call a body?

Part of the power of Arsenijevićs rhetorical questions is their role in illuminating the significant tension between the unspeakable trauma of victims and witnesses, experiencing tragedy and loss, and the exercise of law as a technical practice that seeks to evaluate conflict through textual and instrumental means. This tension is perhaps encapsulated in the desire for legal processes to become 'detached' from wider social and political life, to produce a sphere of decision-making that conforms to a closed bureaucratic rationality. It is this detachment that allows law to present its resolutions as unsullied by the messy contextuality and political influences that permeate wider social practices. As Blomley suggests, it is this presentation of detachment that grants law its moral authority (Blomley 2008, 161). Assuming a hybrid perspective explores the performative nature of such detachment, that it is itself a precarious achievement that is perpetually reinforced through choreography, architecture and performance, rather than existing as a static achievement.

Perhaps the most explicit exploration of the performance of legal detachment has come through Latour's $(2004,2010)$ ethnographic study of the Conseil d'Etat, one of France's supreme courts. Encapsulating a legal anthropological perspective, Latour explores the production of law through the 
circulation of materials, employing an actor-network approach to uncover how legal knowledge is produced through quotidian interactions of a range of human and non-human actors. In these accounts Latour makes a series of direct comparisons between his studies of the practice of science and the laboratory, and the conduct of law and courts:

What makes a comparison between the world of science and law all the more interesting is that both domains emphasize the virtues of a disinterested and unprejudiced approach, based on distance and precision, and in both domains participants speak esoteric languages and reason in carefully cultivated styles (Latour 2004, 73).

The integrity of what Latour $(2004,113)$ terms the "legal edifice" is a product of legal practitioners performing the application of law in apparent (though not actual) separation from society at large.

The focus on hybridity, then, draws attention to the plural material, bodily, and imagined practices through which legal processes assert their authority. The significance of space is not simply as a backdrop against which these processes unfold. Instead we see certain imaginaries of space and place as crucial to the achievement of legal authority, rendering visible spatial frameworks that are often erased through legal discourse. The first, and examined in the following section, is the imagined localization of justice through the creation of the $\mathrm{CBiH}$. The materialization of the Court has challenged this imagined transfer of legal authority since the acquisition of the site, the funding and judiciary of the $\mathrm{CBiH}$ have required close international involvement. But the significance of the materials of the court extends beyond financial support from external actors. The contestation over the selection of location illuminates the wider struggles over the urban landscape in post-conflict $\mathrm{BiH}$, where assertions of victimhood and trauma have been entangled with claims to territory and political authority. Second, foregrounding hybridity illuminates the embodied geographies of the trial processes, and their consequences for public perceptions of the war crimes procedure. In particular we illuminate two contrasting imaginaries of the human body within court space, where legal exchanges requires bodies as instruments (as evidence of crime) against a more affectual 
politics of bearing witness and giving testimony. Through the evidence we trace the considerable entanglement of these forms of embodiment, as the instrumental role of giving testimony is often laden with expectations of certain forms of bodily disposition. These articulations of the material, bodily and imagined spaces of war crimes trials points to the limits of law as an instrument in confronting wartime atrocity.

\section{Imagining Separation}

Men in dark jackets are gathered around the security entrance to the terracotta colored building, smoking and looking intimidating. The gruff-looking police officers wave at me to enter the security area where I and my belongings are subjected to x-ray machines, which are set off, yet I am ushered through without as much as a raised eyebrow. I enter the courtyard of the $\mathrm{CBiH}$ which is littered with small groups of smokers huddling around benches sipping small brown cups of vending machine coffee. I enter the building and immediately present my passport to the reception and am issued a visitors pass for Courtroom 4. As I make my way up the stairs to the courtroom, I notice that the interior of the building is showing signs of aging even though it was only renovated in 2005 [...] After about fifteen minutes of waiting, myself and the two other visitors (they are both wearing accreditation, most likely reporters), are ushered into the courtroom. I chose an uncomfortable seat in the back near to the walls where I notice a layer of soot highlighting cracks in the wall where windows used to be and I wonder which room this was in the CBiH's former life as a JNA barracks and then a military prison during the war. As I continue scanning the room, I look down and see cracks in the floorboards. The defendants enter the courtroom with their police escort which draws my attention to the technical equipment present in the courtroom. The equipment, similar to the facilities, is in need of an update (field notes 25th October 2011).

The account could be a narration of countless visits to the $\mathrm{CBiH}$ where the security routine of crossing from the street to the court became a bodily habit by the end of the research. But this 
familiarity masks the legal and spatial force of this threshold. The security procedures attempt to separate the court space from the landscape of the city, monitoring the bodies and materials that enter the closed space of the court building and outdoor areas. It is a reflection of the spread of security infrastructures that such monitoring is expected (see Graham 2009); it is the norm within $\mathrm{BiH}$ for the passage from public space to a government or intergovernmental building to involve $\mathrm{x}$ rays, surrendering possessions and assuming a new identity card. But, as Mulcahy (2011) documents, this expectation of security is a historical anomaly: legal proceedings emerged in ancient Athens and Western Europe as explicitly public affairs performed in accessible locations such as a town square, a prominent hill or in the shade of a large tree. The sense of public accessibility continues to play an important role in justifying the moral authority of court proceedings, "open justice is treated [by many] as synonymous with the notion of a fair and accurate trial because it provides important witness testimony and the partiality of the judge" (Mulcahy, 2011, 10). Visibility and an audience is a crucial component of the desire for justice being seen to be done.

But as Blomley (2008) and Latour (2009) outline above, law also derives its claim to authority from social and spatial separation. In this case the fencing of the court as an enclave within the city can be read as an attempt to perform the detachment of legal space from the surrounding political landscape of $\mathrm{BiH}$. Where politicians, particularly from the Republika Srpska, have sought to criticize the court as biased against certain ethnic groups or following instructions laid down in Brussels or Washington, the security cordon can be suggestive of detachment and independence. But following Wendy Brown's (2010) examination of recent wall building at state borders, such expectations are perhaps misplaced. For Brown the recent material securitization of borders, for example on the US/Mexico border or around the West Bank in Israel/Palestine, does not signify emboldened state sovereignty but the opposite: the walls are "imago[s] of sovereign state power in the face of its undoing" (Brown, 2010, 25). Rather than suggesting moral authority and detachment, the fencing, security arrangements and monitoring could be identified as evidence of its frail and contested 
authority. The necessity to physically perform separation is a tangible reminder that the $\mathrm{CBiH}$ is an international imposition and has not secured universal public support as an arbiter of law in $\mathrm{BiH}$.

The tension between openness and detachment stems from the materiality of the $\mathrm{CBiH}$ : the establishment of new legal codes cannot be implemented aspatially but have to be brought into existence through the buildings, bodies and materials. The relationship between the concept of the court and its materiality has had profound influence on its political reception within BiH. From the outset the $\mathrm{CBiH}$ was envisaged by supporters within the OHR as an institution that would assist with the consolidation of the $\mathrm{BiH}$ state. It is still understood in those terms; interviews with financial supporters of the $\mathrm{CBiH}$ within the Swedish and Norwegian embassies in Sarajevo explicitly understood the institution as a mechanism for consolidating the $\mathrm{BiH}$ state. That state consolidation is still a central objection of intervening agencies and is a reflection of the highly-decentralized patchwork of territorialities left by the General Framework Agreement for Peace (GFAP, or Dayton Accords) signed in December 1995. Within this agreement power in BiH was decentralized in particular to the two sub-state entities, the Muslim Croat Federation and Republika Srpska, and the small multi-ethnic Brčko District (Toal and Dahlman 2012). In 2003 Lord Paddy Ashdown, then High Representative, stated to a conference on war crimes trials in Sarajevo the state-building function of this new judicial institution:

[...] our joint task can be simply stated: to bring justice to the guilty, to help bring peace to the innocent. That will entail, we are all agreed, more than the International Criminal Tribunal in The Hague, vital though its work has been and continues to be. It must mean justice here too; justice meted out here in $\mathrm{BiH}$. It must involve equipping this country with the means to deal with these issues itself. That is a pre-requisite for becoming a strong, self-sustaining European democracy wedded to the rule of law (Ashdown, 2003).

Ashdown's comments reflect a view that the establishment of the $\mathrm{CBiH}$ can consolidate the postGFAP state and that a new locally-embedded judicial instrument is conducive of democratic politics. 
This aspirational discourse, where intervening agencies can create trusted governmental institutions using a palette of new legal and political codes, has been challenged in practice. As Ashdown suggests, the $\mathrm{CBiH}$ was established to play a complementary role to the ICTY by easing its caseload and helping the tribunal in The Hague to meet its completion mandate. Whilst Orentlicher (2010, 107) suggests that this was a "[m]ajor advance for Bosnia's judicial reckoning for wartime atrocities [...] and one of the ICTY's most important legacies", Bosnian courts (both domestic and military) had been prosecuting suspected war criminals during the conflict using pre-1992 Yugoslav legal codes. This was a necessarily fragmented and localized process, as approaches differed in the Republika Srpska, Muslim-Croat Federation and in Brčko District (and often exhibited variations within these territories). In the post-conflict period international agencies assumed control of the investigation and prosecution of war crimes cases. The 'Rules of the Road' procedure, established under the Rome Agreement of 18 February 1996, directed BiH authorities to submit every case to the ICTY thereby relinquishing control over the ability to indict and arrest alleged war criminals (ICTY 2012b). This obligation ceased in late 2004 on the eve of the establishment of the CBiH (OSCE 2005). Subsequently the OHR began to remodel the BiH judiciary system with the imposition of Criminal Procedure Code of $\mathrm{BiH}^{3}$ and the Criminal Code of $\mathrm{BiH}^{4}$ which saw the judicial landscape move from a civil law tradition heavily influenced by Austria, to a mix of common and civil law procedures similar to that of the ICTY.

The establishment of the new legal codes was enshrined in language of localization and democratization, discourses which suggest a separation between international supervision and the establishment of locally-controlled legal processes. But the novelty of the 2003 Criminal Procedure Code of $\mathrm{BiH}$ and the Criminal Code of $\mathrm{BiH}$ has meant members of the $\mathrm{BiH}$ legal profession have had to simultaneously learn a new judicial system while establishing domestic war crime prosecutions. Significantly, this has created a competence hierarchy elevating international officials, with the imagined credentials of familiarity with the new code of law, above domestic judges who lacked experience working within such legal codes. This hierarchy was reproduced during interviews with 
legal advocacy NGOs who suggested that BiH attorneys lacked investigative skills, the knowledge of how to effectively cross-examine, and experience of the newly-introduced mechanism of plea bargaining. One legal activist in Sarajevo, when discussing prosecutors, stated

The foreign prosecutors have more experience [...] and they play an important role but what I am afraid is when they all leave and there is a tendency for leaving, the local prosecutors will not be capable to put up with pressures and they become exposed to public pressures, pressures from us and media. Those who are good quality prosecutors are looking for a better job, they either become judges or attorneys or they undertake cases and positions not dealing with war crimes. ${ }^{5}$

Of course as one member of a legal advocacy NGO remarked "when we are dealing with an institution without precedent, they are all new to its form and processes" ${ }^{\prime 6}$. Thus rather than reflecting a neutral adjudication of legal competence, the wider distrust of domestic legal professionals could be suggestive of a reification of the international/local hierarchy produced through the adoption of new legal codes.

But the lack of experience of the legal codes was also changing the choreography and performance of the war crimes trials themselves. According to one member of a human rights NGO based in Sarajevo:

[...] the war crimes trials something completely new its nothing to do with their [judges] previous experiences and yes they are experienced in running trials but it's completely a new experience and [...] they have a right to question [under the new system] but they hardly use this at all; they do not get involved [and] they do not see the way they behave in the court can actually influence the witnesses. ${ }^{7}$

The sense of judicial inexperience amongst $\mathrm{BiH}$ legal professionals was further reflected in the series of attempts enacted by international agencies to 'build the capacity' of court employees. Mirroring 
discourses of external expertise that have permeated international development (see Li, 2007), international organizations such as the United Nations Development Program (UNDP) and Organization for Security and Cooperation in Europe (OSCE) have funded a series of training initiatives that have viewed improvement in judicial processes through the lens of increasing the competence of domestic legal personnel. The UNDP funded a three year program entitled Support to Processing War Crimes Cases in BiH-Building Capacities of Cantonal and District Prosecutors' Offices and Court in BiH to Process War Crimes Cases. This program worked to build capacity of cantonal and district prosecutors in processing war crimes cases. The OSCE for example completed in October 2011 the War Crimes Justice Project funded by the European Union and jointly implemented by the OSCE, the ICTY and the United Nations Interregional Crime and Justice Research Institute. The $€ 4$ million project reaching across the legal institution of the former states of Yugoslavia included activities such as training legal professionals on international humanitarian law and hiring thirty young professionals to provide legal support in institutions (OSCE, 2011). These schemes perhaps encapsulate the paradox of elevating international expertise with the aim of establishing domestic legal competences. The imagination of separation, then, is not simply reflected in the tension between detachment and openness, as discussed in the case of the security cordon. It is also exhibited in this uneasy relationship between the creation of a new institution and the lingering need for international stewardship.

But just as the establishment of new criminal codes can erase the legacy of legal expertise, so too can the materials of the court site erase spatial struggles over memory and trauma in BiH. The participation of international judges within the judiciary and the central role of international training in developing the competence of $\mathrm{BiH}$ judges has led to domestic opposition towards the $\mathrm{CBiH}$, in particular from politicians in Republika Srpska. Mirroring the challenges faced integrating the $\mathrm{BiH}$ police (Wisler 2007), army (Vetschera and Damian 2006) or local government agencies (Jeffrey 2006), the establishment of a state judicial institution has been criticized in Republika Srpska as an international imposition, biased against Serbs and failing to follow established legal protocols. 
Rather than remaining an ideological confrontation, these criticisms have found material form in the court building itself, and subsequently resistance has become a struggle over the use and commemoration of space. At the forefront of these concerns has been the selection of the building, located outside the center of Sarajevo in a former JNA barracks. During an interview with a $\mathrm{CBiH}$ official about the location of the court she dismissed any controversy concerning the building by suggesting that the location was chosen because "all the good buildings in the center of town had been taken by other government or international organizations." ${ }^{8}$

In the case of the $\mathrm{CBiH}$ it is not the former JNA barracks role that has provided the source of criticism, but the activities that were undertaken at this complex of buildings during the 1992-5 conflict. While accounts of the usage of the CBiH site vary, individuals loyal to Serb causes have argued that the buildings were used as an internment camp by government forces, pointing to the fact that its name was changed to 'Ramiz Salćin' in 1992 to commemorate a fighter in the Bosnian Government Army who was killed in the siege of Sarajevo. While facts as to the events that unfolded at the $\mathrm{CBiH}$ are sparse, three people (Besim Muderizović, Ramiz Avdović and Iliuan-Nikolae Vintila) were indicted in October 2011 for war crimes against civilians committed at the site (see Balkan Insight, 2012). Radovan Stanković, a now-convicted mass rapist whose case was one of the first to be transferred from the ICTY to the $\mathrm{CBiH}$, used accusations of this usage as a reason to try to prevent the relocation of the trial from The Hague to Sarajevo (see Jeffrey 2012, 142). For Stanković the CBiH could not claim neutrality since it was 'haunted' by the crimes committed in the past, assertions he made during testimony to the ICTY (see ICTY, 2005).

Raising the legacy of violence at the $\mathrm{CBiH}$ is not to say it is an inappropriate site for the $\mathrm{CBiH}$. Rather that the contestation outlined is an almost inevitable legacy in the post-conflict period in $\mathrm{BiH}$, where antagonistic groups wage struggles over legitimacy through the appropriation of place and memory. The argument here is that an appreciation of the materials and history of the $\mathrm{CBiH}$ challenges the aspirations of localization and democratization deployed by international elites at its establishment. 
The imagination of a separation between the court and its wider political setting reflects a desire for a neutral space of deliberation, removed from the context of the fragmented material and political landscape of $\mathrm{BiH}$, reflecting a common imagined virtue of law (Blomley 2008; McEvoy 2007). But this also illustrates a desire to wield law as a mechanism that can unify the fragmented political geographies of $\mathrm{BiH}$. The assertion of universal jurisdiction across the state's territory is imagined to cultivate political consolidation. But this casts law purely as an abstract form of deliberation which necessarily secures the legitimacy of those over who it casts judgment. Such a view ignores either the source of its authority (in this case the external imposition of new laws and criminal procedures) or the materiality of its implementation (through the $\mathrm{CBiH}$ ). Exploring law as a material event taking place in a set of buildings outside the center of Sarajevo has begun to illuminate a more complex geography of law. The realization of the court has highlighted power relations that privilege international expertise where emulation of international legal norms secures the credentials to participate. These forms of local/international dichotomy undermine the sense of localizing justice, while also acting to foment resistance amongst domestic political elites to the establishment of the Court. Such contestation gains credence through the fragmented consociational geography of the GFAP, where space has been aligned to one or another imagined ethnic group. Attempts to insert the court building into this narrative of ethnic space, casting it as allied to one ethnic group, illustrates the challenge of attempting to break GFAP geographies through the establishment of a single legal jurisdiction. The materiality of law embeds this institution in the fragmented geographies of post-conflict $\mathrm{BiH}$.

\section{Embodied Geographies of Trials}

A potted plant and another walkthrough scanner, but this one is unused at the edge of the corridor. The waiting area outside court room six is bare, with seating for about ten people. There is a small courtyard and the door is slid open, a few court staff are outside smoking. I am sitting waiting with a notebook on my lap and the court accreditation round my neck. 
Sitting next to me is a nervous looking man wearing a black leather jacket and blue trousers. He must be about fifty years old. Another, younger, man comes over and offers him a cigarette, he is better dressed and looks relaxed. My neighbor shakes his head and wordlessly declines. There is no one else waiting. Suddenly a Clerk of the Court emerges from the court room to switch the door sign to 'in session' and we make our way in. It is at this moment that the younger man puts on a gown, the older man sitting next me is ushered into the court and I go through a different door to the public gallery. From our close proximity we move into the court room to become lawyer, defendant and researcher (field notes $12^{\text {th }}$ October 2009).

This brief vignette of the experience of one of the authors during a court visit illustrates the role of court space in shaping individual subjectivity, pointing to the use of space, dress and comportment in projecting legal authority and credentials (see Bourdieu 1986). Such shifting positionalities carry spatial implications. First, and in stark terms, these observations underscore Mulcahy's (2011) work on legal architecture, where the design of trial spaces and court buildings shape perceptions and experiences of legal processes, creating insiders and outsiders. Since court room six is the highest security trial chamber within the $\mathrm{CBiH}$ (see figure 3) there is a profound shift between waiting in the circulation area in the corridor to entering the regulated environment of the court space. Where defendants (if not in custody), lawyers, court officials and visitors may mingle within the shared spaces of the court building, the distinctions between these groups are made rigid within the trial spaces themselves. But in making such a distinction there is a danger that we elevate the trials space as the only domain worthy of scrutiny. This is certainly how trial processes are recorded, where courtroom transcripts, testimonies and judicial verdicts become the sole material legacy (see Campbell 1998). In contrast, the memory of those who testify or attended the public gallery often dwelt on these instances of informality as threatening and unwanted, casting defendant and victim in similar terms. Indeed, a number of victim associations remarked on the unequal power relations within these exchanges, since the defendant had the advantage of being accompanied by a defense 
counsel. This led to some seeing this as an expression of a fundamental inequality in the form of trial justice:

The state is on the side of the war crime perpetrators. They have the right to hire two lawyers and they have rights to everything and as for us, courts need us while we are in the court room and when we leave the court room nobody cares for us. ${ }^{9}$

[Figure 3]

In stating the significance of the bodily interactions and accompaniment in shared spaces we must be careful not to draw a distinction between the rigid formality of the court space versus the informal exchanges taking place elsewhere in the building. As demonstrated by Arendt's (1963) account of the trial of Adolf Eichmann, court interactions are themselves performances that warrant critical scholarly attention. For Arendt this involved examining the theatrical characteristics of the legal process, for example the staging of the defendant's dock, the televising of trial proceedings and the broadcast of repeated testimonies of the violence of the Holocaust. Arendt's observations were meant as a criticism, where theatricality was a distraction from the more instrumental legal purpose behind the proceedings. But this approach suggests there is a clear distinction between choreographed theatricality and genuine legal interactions.

The evidence from the trial chambers and witness accounts at the $\mathrm{CBiH}$ suggests a more enmeshed relationship between theatricality and law. As Felman $(2002,9)$ has primed us to expect, the trial proceedings were themselves "physical theatres of justice" where interactions and performances challenged the instrumental image of human bodies as simply vehicles of testimony (see also Hyde, 1997). The disposition of human bodies was central to trial interactions, where various techniques of turning away, placing a head in hands or finger jabbing were enrolled by lawyers and defendants at various times to emphasize specific emotional responses to legal debate. While such practices are characteristic of all trial practices, this is particularly significant in the case of crimes of sexual 
violence committed during war where testimony centers on experiences of bodily violation and alternative forms of evidence (materials, corpses or witnesses) are often absent. Bodies in the court space were therefore inscribed by research informants with difference: most notably between male defendants/lawyers against female witnesses/survivors of sexual violence. Just as the legal process protected defendants through the provision of legal support, one survivor of sexual violence spoke of the incapacity of the legal processes to adequately protect those providing testimony:

As for the treatment of the Prosecution towards victims, from my point of view, they are treated more like perpetrators and not like victims. Why? Why doesn't anybody do something to protect us, why doesn't a judge say: "This cannot be done this way" [...] I have testified numerous times [and they were] showing me photos of the entire military squad, you can imagine how big a shock it was for me. One gets lost. As one lady said one gets silent. I didn't know where I was. I do not remember where I was, what I was looking at in that moment, I was there, I was not here, I cannot describe to you that feeling. ${ }^{10}$

This account illustrates aspects of the bodily experience of bearing witness and giving testimony, where a confrontation with an image of the past renders the witness inarticulate and, in her words, 'lost'. While these comments underscore Felman's (2002) emphasis on the possibilities of retraumatization through bearing witness, they also illuminate the possibilities of political disenfranchisement through trial participation. Where the court physically separates the witness from defendants, the experience of providing witness statements and the interrogative forms of exchange psychologically blur these categories for those testifying for the prosecution. It is not that this blurring suggests openness in trial proceedings where the different legal positions can be interchanged. Rather this comment points to ways in which the legal process cultivates feelings of abjection, lack of credibility and even guilt. In these terms the physical practice of giving testimony, handling evidence and justifying the integrity of one's account cultivates a sense of loss -- either of voice or sense of place. Such a refrain was a recurring story from victim associations and human 
rights NGOs interviewed about the experience of attending the court, that rather than granting participation in a judicial process there was a feeling of disempowerment born of the uncertainty over the nature of the legal process, the unfamiliar surroundings and the forms of legal support offered to the defendant.

This sense of the disempowering nature of trial participation prompted questions from victims associations and NGOs as to who were the target audience for the trials and who were the central protagonists. The physical organization of the court space into trial chamber and public gallery suggests it is the lawyers and judges who are performing for public observers. This certainly accords with the imagination of the court cultivated by international intervening agencies as a step towards localizing war crimes trials where members of the Bosnian citizenry could ensure that justice was seen to be done. But the choreography between audience and performers was not as straightforward in practice. The accounts of witnesses suggested it was their responsibility to perform in a way that conformed to trial expectations. For example one legal analyst spoke of the significance of crying for the legitimacy granted to the evidence:

It is not just expression it's the expectations as well, it's the way they [the judicial trial panel] stop or not, the questions they allow or not [...] it's expressions, it's their expressions of faces [...] I have a statement by one of the women who said that they didn't believe her [about being raped] until she started crying. ${ }^{11}$

In capturing the suspicion held by a number of victims' associations that certain bodily practices granted credence to testimony, this statement also illuminates significant aspects of trial theatricality. Rather than understanding trial processes themselves as simply theatrical, this comment illustrates that elements of theatricality (scripting, characterization, and choreography) are variously imagined by participating agents as shaping their significance to the unfolding trial. This challenges the idea of theatricality as a form of simulation, instead it stresses that forms of bodily presentation, vocal articulation, self-reflexivity and perspective are characteristics of social 
interactions and consequently these are evident within the court room. But more crucially, the sense of testimony as performance underscores a perceived power relation within the practice of bearing witness. Within the courtroom the audience of such practices becomes the legal teams, defendants, and judicial panel, and the testifying witness a reluctant protagonist. Hence the practice of testifying was described by one witness as a form of "exposure" ${ }^{12}$ where their credibility was under scrutiny both during the trial process and later within their local communities as word spread that they had been to the Court. This sense of exposure was exacerbated during the research period (March 2012) as the Court of BiH, to comply with a ruling from the Personal Protection of Data Agency in $\mathrm{BiH}^{13}$, began redacting all indictments and verdicts to erase identifying information of indicted or convicted war criminals. Such anonymity was listed by human rights NGOs as a further barrier to attracting witnesses, as the possibility of establishing a public record of the truth was undermined.

The observation that war crimes trials create senses of disempowerment and re-traumatization amongst those testifying reflects wider legal scholarship concerning the psychological impacts of bearing witness (Orentlicher 2010; Peters 2008). There are, however, a series of conceptual and spatial implications that stem from such an embodied analysis of legal performance at the $\mathrm{CBiH}$. Firstly, this analysis illuminates the potential tensions that exist when a legal institution of transitional justice is used to try and strengthen the coherence of the state. Where the establishment of the court centered on the possibility of universal jurisdiction of BiH territory, the practice of the trials themselves stratifies the social body into distinct legal categories of victim, witness, or defendant. In the abstract these are straightforward legal categories, but the practice of performing law established a set of conceptual hierarchies, where giving testimony was imagined by participants as a disempowering practice. Second, the sense of exposure and re-traumatization experienced by witnesses underscores the need for psychological and legal support institutions. At every stage of the research the absence of state-funded victim or witness support programs was articulated by respondents as a significant barrier to trial completion. Instead, support was provided 
in an ad hoc fashion by victims' associations and human rights NGOs. Relying on civil society organizations to provide witness support functions has led to uneven support across $\mathrm{BiH}$ and, perhaps more significantly, to victims' associations (often explicitly ethno-nationally aligned) becoming key gate-keepers to the provision of support to bear witness.

\section{Conclusion}

The state in $\mathrm{BiH}$ is fragile and contested, while internationally-sponsored attempts to renegotiate its constitution have been both protracted and ultimately unsuccessful. This paper has sketched the limits of using a legal institution to attempt to consolidate a fragmented post-conflict state. The imaginary of singular jurisdiction projects an image of shared citizenship and undermines the devolved and differentiated political spaces of post-Dayton BiH. But the geography of law is more complex than the criminal code under which a citizenry is governed. Drawing on legal geography and legal anthropology this paper has advocated exploring the $\mathrm{CBiH}$ as a precarious material and bodily achievement, one that is constantly reasserted in the face of resistance both by domestic politicians and victims and witnesses.

The argument has drawn theoretical inspiration from work in the field of hybrid geography, scholarship that has sought to examine the "multiple provenances of judgment" (Amin 2012, 5), exploring the interplay of beings and things in the performance of social life. The purpose of such a perspective extends beyond providing a more nuanced examination of legal processes; rather it is to unsettle the imagined purity of law as a mechanistic process of conflict resolution separate from wider social and political contexts. As McEvoy (2007) and Latour (2010) have illustrated, the production of law is constituted through - and reliant upon - a wealth of non-legal actors, spaces and materials. The ideal of separation is structured around the imaginary of legal exchanges as unsullied by social and political interests, and in the case of the $\mathrm{CBiH}$ through its representation by international agencies as an institution that is autonomous of international agendas with a jurisdiction over the entirety of BiH's territory. But the nature of the CBiH's establishment, the 
constitution of its judiciary and even the selection of the building have challenged this account of purity and separation. Perhaps more significantly, the contestation over the court has led to continued international supervision of legal processes, undermining a sense of the $\mathrm{CBiH}$ as an illustration of the localization of transitional justice.

While the materials of the court building shaped imagined geographies of political alignment of the court, the practices of the trials themselves illuminate the social consequences of legal theatricality. The embodied experience of participating in the trials is suggestive of a nested set of audience positions, at one scale constituting the lawyers, defense counsel and judicial panel, at another the scale of $\mathrm{BiH}$ as a whole as the trial processes attempt to illustrate that justice is being done for the crimes of the past. But a third audience scale is constituted of those outside $\mathrm{BiH}$, where the process of war crimes trials is a key component of the completion mandate of the ICTY and a requirement of pre-accession talks for membership of the European Union. It is at this scale we see a potential tension between different audiences of trial performance. The mechanisms for judging the success of the $\mathrm{CBiH}$ is through quantitative measurement of trial completion and the allied financial cost of delivering war crimes trials through this institution (European Commission 2012, 13). In this optic the physical and psychological effects of the trials may be overlooked, as the more instrumental question of trial completion takes precedent over the physical and social effects of law. One of the consequences of this analysis is the central role played by voluntary and non-governmental organizations in delivering victim support and often ensuring the smooth running of trials through the provision of witnesses.

Finally, this account contributes to debates in legal geography by exploring the spatial implications of attempts to assert a new legal institution. The challenge for the analyst is to grasp the numerous sources of authority in a post-conflict environment characterized by intense international intervention and more localized ethnocracies (Toal and Dahlman 2012). Tensions between different interests are not erased by the establishment of universal jurisdiction, but are rather illuminated 
through its contested and incomplete implementation. Examining the material and embodied nature of the $\mathrm{CBiH}$ suggests the limits of law as a mechanism of justice, in particular in the absence of more restorative or reconciliatory practices.

\footnotetext{
${ }^{1}$ The leading civilian organisation implementing 1995's General Framework Agreement for Peace (Dayton Accords).

${ }^{2}$ For example, "[f]or the first three years of the five-year transitional period (2005-2007), the [trial] panels were composed of a presiding national judge and two international judges. In the second two years (2008 and 2009) the number of international judges reduces to one per panel, and by the end of the transitional period...all remaining internationals will be replaced by national judges" (Adbulhak 2009, 339). At the time of writing international judges remained on certain panels but they are due to be phased out at the beginning of 2013.

${ }^{3}$ Official Gazette of Bosnia and Herzegovina, 3/03

${ }^{4}$ Official Gazette of Bosnia and Herzegovina No. 3/03, 32/03, 37/03, 54/04, 61/04, 30/05, 53/06, 55/06, 32/07

${ }^{5}$ Interview with Legal Activist and Campaigner, Sarajevo, $\mathrm{BiH}, 20^{\text {th }}$ June 2012.

${ }^{6}$ Interview with Legal Advocacy NGO, Sarajevo, BiH, $4^{\text {th }}$ November 2011.

${ }^{7}$ Interview with member of Human Rights NGO, Sarajevo, BiH, $29^{\text {th }}$ November 2011.

${ }^{8}$ Interview with CBiH Public Relations Official, Sarajevo, BiH $8{ }^{\text {th }}$ October 2009.

${ }^{9}$ President of Women's' Victim Association, 20 September 2012, Project Workshop.

${ }^{10}$ Victims' Association Tuzla, $19^{\text {th }}$ April 2012.

${ }^{11}$ Victims' Association Tuzla, $19^{\text {th }}$ April 2012.

${ }^{12}$ Interview with Legal Advocacy NGO, Prijedor 23 $3^{\text {rd }}$ May 2012.

${ }^{13}$ The Agency was complying with a ruling passed by the Parliamentary Assembly of BiH on March $26^{\text {th }} 2006$, see Official Gazette of Bosnia and Herzegovina, 49/06.
} 


\section{Bibliography}

Abdulhak, T. 2009. Building sustainable capacities-from an international tribunal to a domestic war crimes chamber for Bosnia and Herzegovina. International Criminal Law Review, 9: 335-358.

Amin, A. 2012. Land of Strangers. Cambridge: Polity.

Arendt, H. 1963. Eichmann in Jerusalem. London: Penguin.

Armatta, J. 2010. Twighlight of Impunity The War Crimes Trial of Slobodan Milosevic. Durham North Carolina: Duke University Press.

Arsenijević, D. 2011. Gendering the Bone: The Politics of Memory in Bosnia and Herzegovina. Journal of Cultural Research 15: 193-205.

Ashdown, P. 2003. Remarks By The High Representative To The Conference On Domestic Prosecution Of War Crimes http://www.ohr.int/ohr-dept/presso/presssp/default.asp?content id=28906 Accessed $8^{\text {th }}$ January 2013.

Balkan Insight. 2012. "Horrific Conditions" in Viktor Bubanj Barracks. http://www.balkaninsight.com/en/article/witness-recalls-horrific-conditions-in-viktor-bubanj Accessed 8th January 2013.

Blomley, N. 1994. Law, Space and the Geography of Power. New York and London: The Guildford Press.

-- 2003. Law, Property, and the Geography of Violence: The Frontier, the Survey, and the Grid. Annals of the Association of American Geographers 93 (1): 121-141.

-- 2008. Making Space for Law. In The Sage Handbook of Political Geography eds. K. Cox, M. Low and J. Robinson, 155-168. London: Sage.

Bourdieu, P. 1986. The force of law: Toward a sociology of the juridical field. Hastings Law Journal, 38: 805-854.

Brown, W. 2010. Walled States, Waning Sovereignty. Cambridge: MIT Press.

Butler, J. 1990. Gender Trouble: Feminism and the Subversion of Identity. London: Routledge. 
Campbell, D. 1998. National Deconstruction: Violence, Identity and Justice in Bosnia. Minneapolis: University of Minnesota Press.

Commission of Experts. 1992. Final Report of the Commission of Experts Established Pursuant to Security Council Resolution 780 (1992), UN Doc. S/1994/674.

Coward, M. 2009. Urbicide: The Politics of Urban Destruction. Abingdon: Routledge.

Cover, R. 1985. The Folktales of Justice: Tales of Jurisdiction. Capital University Law Review 14: 179203.

Delaney, D. 2001. Introduction: Globalization and Law. In The Legal Geographies Reader: Law, Power and Space, eds. N. Blomley, D. Delaney and R. T. Ford, 252-255. Oxford: Blackwell.

Derrida, J. 1994. Specters of Marx: the state of debt, the work of mourning and the new international. New York: Routledge.

De Sousa Santos, B. 1987. Law: A Map of Misreading-Toward a Postmodern Conception of Law. Journal of Law and Society 14: 279-302.

Dougherty, B. 2004. Right-sizing international criminal justice: the hybrid experiment of the Special Court for Sierra Leone. International Affairs $8: 311-328$.

Elden, S. 2009. Territory and Terror the Spatial Extent of Sovereignty. Minneapolis: University of Minnesota Press.

European Commission 2012. Bosnia and Herzegovina 2012 Progress Report http://ec.europa.eu/enlargement/pdf/key documents/2012/package/ba rapport 2012 en. pdf Accessed 15th July 2013

Felman, S. 2002. The Juridical Unconscious: Trials and Traumas in the Twentieth Century. Cambridge: Harvard University Press.

Ferguson, J. 2006. Global Shadows: Africa in the Neoliberal World Order. Durham: Duke University Press.

Goldstone, R. 2000. For Humanity: Reflections of a War Crimes Investigator. New Haven: Yale University Press.

Graham, S. 2009. The urban 'battlespace'. Theory, Culture and Society 26 (7-8):278-288. 
Gregory, D. 2007. Vanishing Points Law Violence and Exception in the Global Prison. In Violent Geographies: Fear, Terror and Political Violence, eds. D. Gregory and A. Pred, 205-236. New York and Milton Keynes: Routledge.

Hazan, P. 2004. Justice in a Time of War: The True Story Behind the International Criminal Tribunal for the Former Yugoslavia. College Station: Texas A \& M University Press.

Hyde, A. 1997. Bodies of Law. Princeton: Princeton University Press.

International Criminal Tribunal for the former Yugoslavia. 2005. Trial Session 4th March 2005 Radovan Stanković. http://www.icty.org/x/cases/stankovic/trans/en/050304SC.htm Accessed January $8^{\text {th }} 2013$.

-- 2012a. Mandate and Jurisdiction http://www.icty.org/sid/320 Accessed January 8th 2013.

-- 2012b. Working with the Region. http://www.icty.org/sid/96 Accessed January 8th 2013.

Jeffrey, A. 2006. Building state capacity in post-conflict Bosnia and Herzegovina: The case of Brcko District. Political Geography 25 (2):203-227.

-- 2011. The political geographies of transitional justice. Transactions of the Institute of British Geographers, 36: 344-359.

-- 2012. The Improvised State: Sovereignty, Performance and Agency in Dayton Bosnia. Oxford: Wiley-Blackwell.

Latour, B. 2004. Scientific Objects and Legal Objectivity. In Law, Anthropology, and the Constitution of the Social Making Persons and Things, eds. A. Pottage and M. Mundy, 73-114. Cambridge: Cambridge University Press.

-- 2010. The Making of Law. Cambridge: Polity Press.

Law, J. 1994. Organizing Modernity. Oxford: Wiley-Blackwell.

Li, T. M. 2007. The Will to Improve: Governmentality, Development and the Practice of Politics. Durham, NC: Duke University Press.

McEvoy, K. 2007. Beyond Legalism: Towards a Thicker Understanding of Transitional Justice. Journal of Law and Society 34: 411-440. 
Mulcahy, L. 2011. Legal Architecture: Justice, Due Process and the Place of Law. Abingdon: GlassHouse.

Navaro-Yashin, Y. 2012. The Make-Believe Space: Affective Geography in a Postwar Polity. Durham: Yale University Press.

Nettelfield, L. 2010. Courting Democracy in Bosnia and Herzegovina: The Hague Tribunal's impact in a Postwar State. Cambridge: Cambridge University Press.

Nezavisne novine. 2012. Dodik: Sud odlučio o Srebrenici pod pritiskom stranaca

http://www.nezavisne.com/novosti/bih/Dodik-Apelacioni-sud-odlucio-o-Srebrenici-podpritiskom-stranaca-171147.html Accessed January 8th 2013.

Peters, J. S. 2008. "Legal Performance Good and Bad." Law, Culture, and the Humanities 4: 179-200.

Pottage, A. 2004. Introduction: the fabrication of persons and things. In Law, Anthropology, and the Constitution of the Social Making Persons and Things, eds. A. Pottage and M. Mundy, 1-39. Cambridge: Cambridge University Press.

Orentlicher, D. 2010. That someone guilty be punished: the impact of the ICTY in Bosnia. Open Society Initiative and the International Centre for Transitional Justice: New York

Organisation for Security and Cooperation in Europe. 2005. War Crimes Trials Before the Domestic Courts of Bosnia and Herzegovina: Progress and Obstacles. Sarajevo: OSCE.

-- 2011. War Crimes Justice Project strengthens national capacities to handle war crimes cases http://www.oscebih.org/News.aspx?newsid=128\&lang=EN Accessed January $8^{\text {th }} 2013$.

Silber, L. and Little, A. 1995. The Death of Yugoslavia. London: Penguin.

Toal, G. and Dahlman, C. 2012. Bosnia Remade: Ethnic Cleansing and Its Reversal. Oxford: Oxford University Press.

United Nations Security Council. 2004. The Rule of Law and Transitional Justice in Conflict and PostConflict Societies. United Nations, New York 1-24

Vetschera, H. and Damian, M. M. 2006. "Security Sector Reform in Bosnia and Herzegovina: The Role of the International Community." International Peacekeeping 13: 28-42. 
Whatmore, S. 2002. Hybrid Geographies: Natures, Cultures, Spaces. London: Sage.

Wisler, D. 2007. The International Civilian Police Mission in Bosnia and Herzegovina: From Democratization to Nation-Building. Police Practice and Research: An International Journal 8: 253-268. 
List of Figures

Figure 1: Map of Sarajevo with the Court of Bosnia and Herzegovina (Source: Alex Jeffrey)

Figure 2: The Court of Bosnia and Herzegovina (Source: Alex Jeffrey)

Figure 3: Courtroom 6 at the Court of Bosnia and Herzegovina (Source: Alex Jeffrey) 